
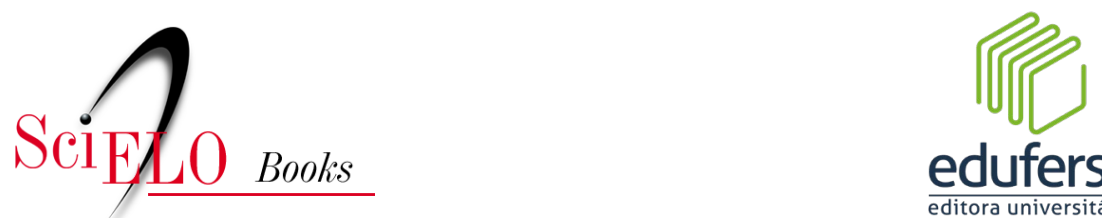

\title{
11 - Pós-colheita, industrialização e forma de consumo
}

\author{
Francisco Xavier de Souza \\ Francisco de Queiroz Porto Filho \\ Nouglas Veloso Barbosa Mendes
}

\section{SciELO Books / SciELO Livros / SciELO Libros}

SOUZA, F. X., PORTO FILHO, F. Q., and MENDES, N. V. B. Póscolheita, industrialização e forma de consumo. In: Umbucajazeira: descrição e técnicas de cultivo [online]. Mossoró: EdUFERSA, 2020, pp. 84-86. ISBN: 978-65-87108-02-5. https://doi.org/10.7476/9786587108599.0013.

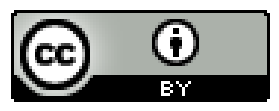

All the contents of this work, except where otherwise noted, is licensed under a Creative Commons Attribution 4.0 International license.

Todo o conteúdo deste trabalho, exceto quando houver ressalva, é publicado sob a licença Creative Commons Atribição 4.0.

Todo el contenido de esta obra, excepto donde se indique lo contrario, está bajo licencia de la licencia Creative Commons Reconocimento 4.0. 


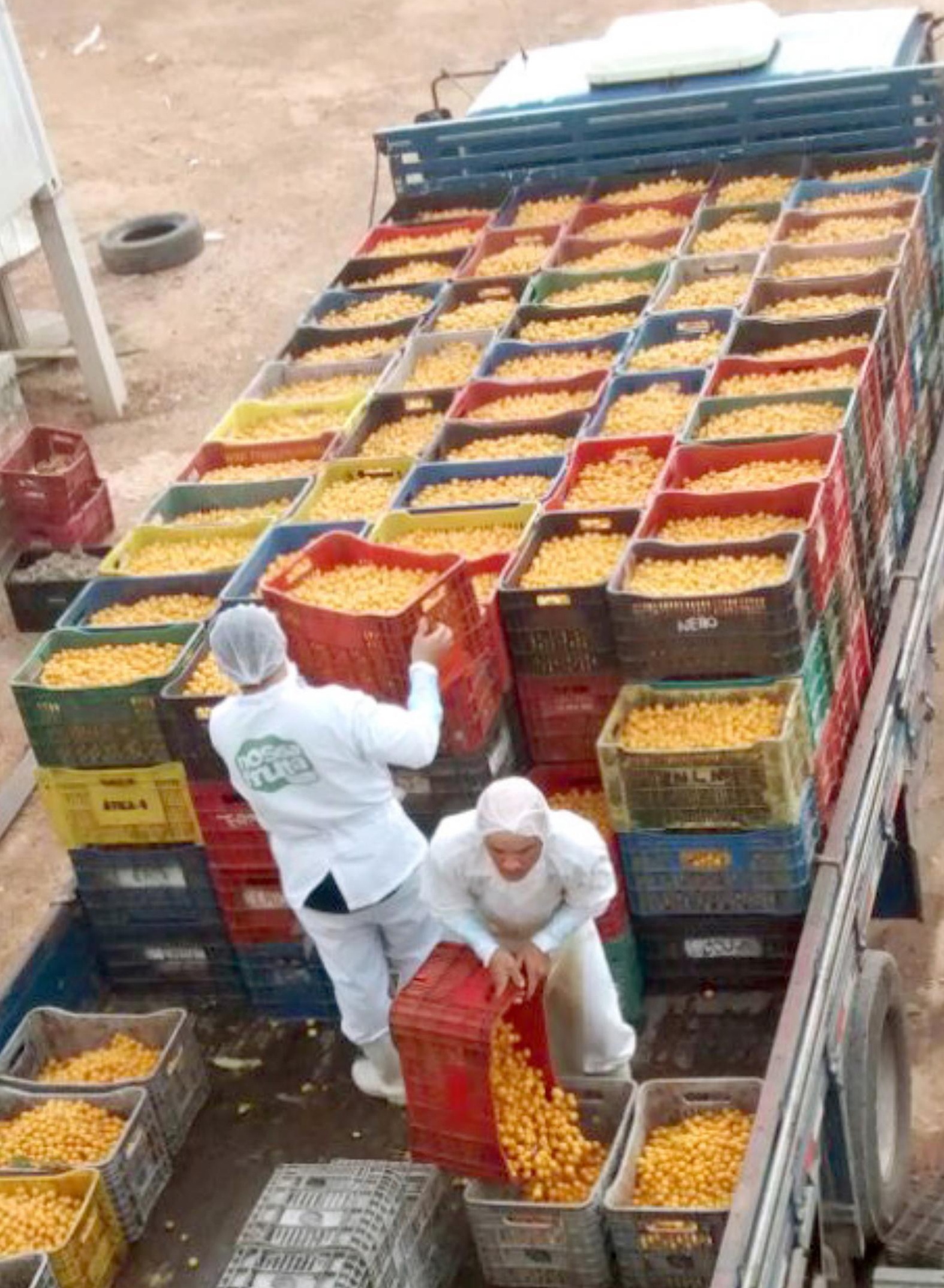




\section{1 \\ PÓS-COLHEITA, \\ INDUSTRIALIZAÇÃO E \\ FORMA DE CONSUMO}

crescente a participação dos frutos da umbu-cajazeira, os umbu-cajás ou as cajaranas, no agronegócio do Nordeste, principalmente como fruta fresca ou processada, como polpa, sucos e sorvetes de excelente sabor, aroma e qualidade nutricionais e agroindustriais.

Os frutos são muito perecíveis. Colhidos maduros e armazenados em temperatura ambiente, têm pouco tempo de prateleira e logo se deterioram, pois possuem cascas finas e teores de sólidos solúveis que aceleram a deterioração.

A literatura sobre pós-colheita do umbu-cajá é incipiente. Aroucha et al. (2012) afirmam que umbu-cajás colhidos de vez e armazenados em câmara fria mantiveram suas qualidades organolépticas por 14 dias.

O congelamento é uma operação onerosa que necessita de soluções para barateamento nas fases de pós-colheita e industrialização, pois o armazenamento de frutos e produtos processados por longos períodos é inviável economicamente. Todavia, é, até o momento, a forma de conservação que as agroindústrias utilizam.

As maiores dificuldades enfrentadas por fruticultores, comerciantes e empresas que trabalham com frutos e produtos processados é a manutenção da cadeia de frio para a conservação da qualidade até o consumidor final. O estádio de maturação adequado dos frutos para a colheita e a temperatura de armazenamento refrigerado determinam o potencial de 
conservação pós-colheita. A refrigeração é uma técnica onerosa, porém de grande importância para o prolongamento da vida útil dos frutos in natura e da polpa, sem a perda das características para consumo.

Quanto à industrialização e à forma de consumo da polpa de umbu-cajá, pode-se dizer que todas as receitas utilizadas com o umbu podem ser feitas com o umbu-cajá.

A principal forma de consumo da polpa é na forma de suco, pela adição de água e açúcar a gosto. Entretanto, com a polpa podem ser produzidos doces, geleias, mousses, umbu-cajaranadas, drinks, entre outras, além de compor misturas (blends) de polpas, sucos, néctares e sorvetes de outras fruteiras. 